\title{
PROSES ARANSEMEN LAGU DALAM BENTUK MUSIK TEMA DAN VARIASI
}

\author{
Oleh: \\ Feri Firmansyah \\ (Dosen FKIP Program Studi Pendidikan Sendratasik Universitas PGRI Palembang)
}

\begin{abstract}
Abstrak
Artikel ini berisi tentang proses dan teknik aransemen musik yang dibuat dalam bentuk musik tema dan variasi. Penulisan ini bertujuan untuk memberikan salah satu alternatif proses dalam mengaransemen lagu. Aransemen juga merupakan salah satu kegiatan untuk melestarikan sebuah karya musik. Proses aransemen dan beberapa teknik yang digunakan akan diurai secara ringkas kemudian dipaparkan secara deskriptif. Ada enam hal yang dapat diperhatikan dalam proses mengaransemen lagu, yaitu (1) memahami latar belakang komponis dan makna teks lagunya, (2) melakukan analisis bentuk dan struktur lagu yang akan diaransemen, dan memahami unsur-unsur musiknya (3) pengetahuan tentang instrumen musik yang dipilih , (4) bentuk aransemen musik, (5) penggunaan teknik dalam mengolah unsur-unsur musik pada lagu yang akan diaransemen, (6) penulisan notasi. Dengan mengikuti proses aransemen yang dijelaskan dalam artikel ini, dapat membantu dalam kegiatan belajar mengaransemen musik, khususnya bagi akademisi musik.
\end{abstract}

\section{A. PENDAHULUAN}

Proses penyampaian ide musikal sering dilakukan dengan menyusun ide tersebut dalam sebuah komposisi musik. Selain itu, komposer dapat juga menuangkan idenya dalam sebuah aransemen. Pembuat aransemen juga sering melakukan hal-hal yang lebih jauh melebihi modifikasi yang semestinya, menguraikan detil-detil karya asli sampai memperoleh arti yang baru dan menambah sendiri materi-materi baru yang tidak ada hubungannya dengan karya aslinya (Wilson, 1985: 42-43). Menurut Percy A. Scholes aransemen adalah mengadaptasikan satu medium musik dari musik asli yang disusun menjadi bentuk lain (Scholes, Tanpa Tahun: 53). Dalam pengertian ini seorang arranger sangatlah bebas dalam mengolah musik yang akan diaransemen termasuk menentukan bentuk musik yang menjadi konsep dasar aransemennya. Ide-ide musikalnya akan 
dimasukkan ke dalam aransemen, walaupun ide tersebut tidak ada hubungan dengan musik aslinya.

Aransemen memang erat dengan sebuah kreativitas, seorang arranger dituntut untuk dapat mengolah sebuah karya musik yang akan diaransemen, agar karya musik tersebut dapat menjadi lebih artisitik dan memiliki nilai estetis. Menurut Don Michael Randel aransemen adalah menyadur suatu komposisi yang berlainan dari komposisi aslinya biasanya dengan tujuan mempertahankan unsur-unsur esensi musikalnya, juga dengan suatu proses adaptasi yang sedemikian rupa (Randel, 1986: 53). Variasi sebuah ide tematis dapat saja dihasilkan dengan banyak jalan, hal ini dapat dilakukan dengan mengolah elemen musikal, yaitu melodi, ritme, harmoni, dinamika, timbre dan ekspresi (Miller, Tanpa Tahun: 153). Dalam pengertian yang lain aransemen adalah penulisan kembali sebuah komposisi dengan instrumen berbeda dari karya aslinya, dapat dikatakan sebagai transkripsi (perpindahan/salinan) (Ammer, 1972:1 2). Hal ini menunjukkan bahwa seorang arranger dapat menggunakan instrumen musik apa saja dalam mengaransemen sebuah karya musik.

Bukan hanya sebuah karya musik instrumentalia saja yang dapat diaransemen, namun yang berkembang saat ini lagu-lagu diaransemen ke dalam bentuk instrumentalia. Seperti yang dilakukan oleh Erwin Gutawa yang mengaransemen lagu-lagu koesplus ke format orkestra secara instrumentalia. Oleh karena itu, penting bagi seorang arranger memiliki pengetahuan yang luas tentang aransemen agar dapat mengembangkan dan mengolah lagu tersebut menjadi lebih artistik. Hal-hal yang menjadi tantangan adalah, bagaimana kita dapat mengadaptasikan sebuah nyanyian ke dalam bentuk instrumentalia, dan mengolah struktur serta mengembangkan unsur-unsur musik dalam lagu tersebut.

Pada musik barat bentuk-bentuk musik yang konvensional di antaranya sonata, concerto, tema dan variasi, dan menuet. Bentuk-bentuk tersebut dapat kita aplikasikan atau kita gunakan untuk dijadikan sebagai bentuk dalam sebuah aransemen musik, seperti lagu Sepasang Mata Bola yang memiliki bentuk dua bagian diaransemen dengan bentuk tema dan variasi. Melodi dari lagu Sepasang Mata Bola itu sendiri dijadikan tema, dan variasinya dibuat sedemikian rupa dengan menggunakan beberapa prosedur dan teknik yang ada dalam mengolah lagu tersebut, sehingga terlihat dan terdengar ada sebuah 
pengembangan dari melodi aslinya. Salah satu aransemen yang mengunakan bentuk tema dan variasi, yaitu aransemen Jazeed Djamin untuk lagu Sepasang Mata Bola. Beliau mengaransemen lagu tersebut dengan sembilan variasi. Selain itu, aransemen Joko Lemaz untuk lagu Indonesia Pusaka dalam bentuk tema dan variasi.

Dari uraian di atas, dicoba untuk menjelaskan teknik dan proses aransemen lagu dalam bentuk tema dan variasi. Dalam mengolah unsur-unsur musik yang ada perlu sebuah pengetahuan tentang hal tersebut. Dalam tulisan ini selain menawarkan konsep tema dan variasi dalam proses mengaransemen lagu, akan dijabarkan juga hal-hal lain yang mendukung dalam proses aransemen itu sendiri. Dengan mengikuti proses aransemen yang dijelaskan dalam artikel ini, dapat membantu dalam kegiatan belajar mengaransemen musik, khususnya bagi akademisi musik. Selanjtunya, Artikel ini akan dipaparkan secara deskriptif, pengumpulan data dilakukan melalui observasi dan studi pustaka.

\section{B.METODE PENELITIAN}

Metode penelitian yang digunakan yakni deskriptif kualitatif, sehingga akan di deskripsikan sesuai dengan hasil analisis data yang telah tersaring yang didapat di lokasi penelitian. Metode deskriptif adalah suatu metode dalam pencarian fakta status kelompok manusia, suatu objek, suatu kondisi, suatu sistem pemikiran ataupun suatu peristiwa pada masa sekarang dengan interprestasi yang tepat (Sudarmayanti, dkk., 2002: 33).

\section{C.PEMBAHASAN}

\section{Proses Pengarapan Aransemen}

Pada bagian ini akan dijelaskan proses pengarapan aransemen yang dimulai dengan melihat sekilas riwayat hidup dan memahami makna teks lagu. Selanjutnya menganalisis bentuk dan struktur lagu yang akan diaransemen. Setelah itu akan dipaparkan tentang pemilihan instrumen dan bentuk musik yang akan digunakan dalam mengaransemen lagu. Pada bagian akhir akan dijelaskan teknik yang digunakan dalam mengolah unsur musik dan penulisan notasinya. 


\section{Memahami Latar Belakang Komponis}

Memahami latar belakang komponis dapat menjadi stimulan untuk mendapatkan ide-ide musikal dalam aransemen nantinya. Mungkin sangat jarang yang melakukan kajian tentang hal ini, namun pengalaman dari arranger, seperti Singgih Sanjaya, mengatakan bahwa latar belakang komponis dapat mempengaruhi dalam proses aransemen. Singgih Sanjaya juga menambahkan, bahwa dalam sebuah aransemen musik, ciri musikal yang melekat dari komponis menjadi inspirasi yang signifikan dalam mengisi aransemen musik itu nanti (Singgih, wawancara: 12 Desember 2007). Pernyataan Singgih Sanjaya tersebut mengisyaratkan bahwa penting bagi seorang arangger untuk memahami latar belakang komponis, serta mengetahui hal-hal yang berhubungan dengan pembentukan dan perkembangan seorang komponis dalam bermusik, agar muncul stimulan dalam proses aransemennya nanti.

\section{Memahami Makna Teks Lagu}

Dengan memahami sekilas riwayat hidup komponis, mungkin sudah banyak ide musikal yang muncul untuk memberikan warna dalam aransemen sebuah lagu. Hal ini dapat diperkaya lagi dengan memahami maksud ataupun makna yang terkandung dari teks lagu tersebut. Pada bagian ini akan dicontohkan bagaimana memahami makna teks dari lagu Sepasang Mata Bola sebagai berikut :

\section{Sepasang Mata Bola}

Hampir malam di Yogya, ketika keretaku tiba

Remang-remang cuaca, terkejut aku tiba-tiba

Dua mata memandang, Seolah-olah dia berkata

Lindungi aku pahlawan, dari pada si angkara murka

Sepasang mata bola, dari balik jendela

Datang dari Jakarta, nuju medan perwira

Kagumku melihatnya, sinar sang perwira rela

Pergilah pahlawanku, jangan bimbang ragu bersama doaku (Siagian, 1975: 79) 
Sepasang Mata Bola, lagu yang mengajak setiap orang untuk melihat kembali langkah pemuda pejuang yang berangkat ke medan juang, diciptakan Ismail Marzuki saat hendak menghadiri peringatan Hari Radio 1946 di kota Solo. Ketika tiba di stasiun Yogyakarta pada senja hari, melalui jendela kereta api Ismail meyaksikan sebuah pemandangan yang mengharukan. Dia mengabadikannya dalam lagu Sepasang Mata Bola, dialog melalui pandangan mata antara rakyat kecil dan pejuang (Esha, 2005: 70).

Dalam teks lagu tersebut mengisahkan tentang tokoh "aku" yang jatuh cinta pada pandangan pertama dalam konteks perjuangan. Teks lagu diawali oleh "aku" pejuang yang tiba di stasiun kereta api Yogyakarta dari Jakarta. "Aku" pejuang yang terkejut dan terpikat melihat seorang gadis berbola mata besar sedang memandang dirinya. Dunia khayal "aku" tekspun berkembang liar. Dia seolah-olah mendengar ucapan tersirat dari sinar mata gadis itu yang sekereta api dari Jakarta untuk berjuang di Yogyakarta : "lindungi aku pahlawan daripada siangkara murka" serta "pergilah pahlawanku jangan bimbang ragu bersama doaku" (Esha, 2005: 118)

Bagi generasi 1945 yang mengalami langsung revolusi fisik, kisah para pejuang yang naik kereta api dari Jakarta berangkat menuju Yogyakarta, tentu akan mengingatkan mereka pada masa perang mempertahankan kemerdekaan sesudah proklamasi 17 Agustus 1945. Tidak hanya kaum lelaki, para perempuan pun ikut berjuang sampai front terdepan. Syair dan lagu Sepasang Mata Bola terkait dengan kisah perang semacam itu. Keromantisan dan semangat juang Ismail Marzuki jelas terungkap lewat syair lagu itu (Esha, 2005: 118).

\section{Analisis Bentuk dan Struktur Lagu}

Proses pengembangan satu melodi lagu dapat kita lakukan dengan baik, setelah kita memahami bentuk dan struktur lagu tersebut beserta unsur-unsur musik yang mendukungnya. Oleh karena itu perlu dilakukan analisis terhadap lagu tersebut secara mendetail dengan mengetahui motif, frase, periode, dan unsur musik lainnya seperti tempo, nada dasar, dan tangga nada yang digunakan dalam lagu tersebut. Analisis bentuk dan struktur lagu yang dimaksudkan salah satunya dapat mengacu pada ilmu analisis bentuk dan struktur musik barat. 
Sebelum masuk dalam proses analisis bentuk dan struktur lagu, dilakukan studi ataupun memahami beberapa hal yang mendukung analisis itu sendiri. Hal ini merupakan dasar-dasar dalam studi analisis musik dan juga nantinya akan membantu dalam proses aransemen lagu, di antaranya adalah penjelasan tentang figure, motif, frase, kadens dan periode. Selain itu unsur-unsur musik seperti melodi, ritme, harmoni, ekspresi, dan dinamika yang ada pada notasi lagu juga harus dipahami. Dengan memahami bentuk dan struktur serta unsur-unsur musik pada lagu tersebut, dapat digunakan sebagai pijakan ataupun konsep dasar dalam mengembangkan lagu yang akan diaransemen.

\section{a. Figur}

Figur merupakan suatu unit konstruksi terkecil dalam musik yang setidak-tidaknya berisi satu karakteristik irama dan satu karakteristik interval (Stein, 1979: 3). Selain itu figur tidak memiliki arti jika berdiri sendiri, tetapi dengan pengolahan akan lebih mempunyai arti, seperti dibuat sekwen. Istilah motif kadang digunakan sebagai persamaan dari figur. Pembedaan yang paling umum adalah figur sebagai suatu unit pengiring atau pola tertentu seperti yang terdapat pada karya-karya etude beberapa karya barok dan motif sebagai suatu partikel tematik (Stein, 1979: 3).

\section{b. Motif}

Motif merupakan sekelompok nada yang terdiri dari 3 nada atau lebih yang memiliki arti musikal (Susilo, 1999: 3). Sedangkan menurut Karl-Edmund Prier motif merupakan unsur lagu yang terdiri dari sejumlah nada yang dipersatukan dengan suatu gagasan/ide. Sama seperti figure motif biasanya diulang-ulang dan diolah seperti augmentasi, elisi.

\section{c. Kadens}

Kadens adalah suatu titik istirahat yang menandai ujung suatu frase atau bagian. Dalam diktat kuliah IImu Analisis Musik Oleh Andre Indrawan dijelaskan kadens merupakan pungtuasi dalam musik sebagai titik peristirahatan yang tersusun dari serangkaian akor-akor yang bergerak sedemikian rupa untuk menandai berakhirnya suatu frase atau seksi. Kadens memiliki dua fungsi yaitu menandai berakhirnya suatu frase atau seksi dan memulai sesuatu yang lain (Stein, 1979: 10). Jika memulai sesuatu maka kadens yang datang sebelumnya tidak menandakan berakhirnya suatu kalimat ataupun 
bagian dan berperan sebagai jembatan atau figure perpindahan. Kadens dapat dikelompokkan dalam 4 jenis yaitu

1. Kadens Autentik

Kadens autentik mengunakan susunan akor : V-I, dalam hal ini mewakili setiap formasi dominant (misalnya V7,vii7, dll) (Stein, 1979: 10).

Kadens autentik memliki dua kategori. Yang pertama adalah kadens autentik sempurna yaitu jika akar trinada tampil di kedua suara luar (sopran dan bas) dari akor tonik (Stein, 1979: 10).

Yang kedua adalah kadens autentik tak sempurna yaitu jika terts atau kwint dari tonika hadir pada suara luar (sopran dan bass), atau jika terts terdapat pada suara bass (Stein, 1979: 11).

2. Kadens Plagal

Kadens plagal menggunakan susunan akor : IV-I (Stein, 1979: 11).

3. Kadens deseptif

Kadens desptif adalah pergerakan akor V ke VI atau dari akor $\mathrm{V}$ ke harmoni apa saja yang tidak diduga kehadirannya (Stein, 1979: 11).

\section{Kadens Setengah}

Akor-akor dari kadens setengah biasanya bergerak dari akor apa saja menuju akor V. Walaupun demikian dalam musik abad ke 19 dan ke 20, kadang-kadang kalimat musik berakhir pada akor II, III atau IV, sehingga fenomena seperti ini perlu dipertimbangkan juga sebagai kadens setengah (Stein, 1979: 1).

\section{d. Semi frase}

Semi frase adalah bagian dari frase yang dibentuk oleh motif-motif (Jones, 1974: 102).

\section{e. Frase}

Frase adalah unit struktural yang terkecil dalam musik dan merupakan pernyataan musik atau ide musikal yang dengan jelas dibatasi oleh semacam titik akhir yang biasanya 
berupa kadens (Susilo, 1999: 15). Guna memperoleh pemahaman tentang frase Leon Stein menawarkan empat asumsi. Yang pertama bahwa frase konvesional umumnya adalah sebuah unit yang terdiri dari empat birama, yang kedua bahwa frase adalah unit terpendek yang diakhiri dengan kadens, yang ketiga bahwa sebuah frase biasanya memiliki hubungan dengan frase-frase lain, dan yang keempat bahwa pada dasarnya frase adalah basis struktural bentuk-bentuk homofonis yang juga diterapkan pada strukturstruktur poliponis tertentu (Stein, 1979: 22).

\section{f. Periode}

Jika dua atau lebih frase digabung dalam sebuah wujud yang bersambung sehingga bersama-sama membentuk sebuah unit seksional, struktur demikian disebut periode (Miller, tanpa tahun: 166). Ada tiga bentuk periode yaitu :

- Periode standar, adalah periode yang terdiri dari frase anteseden yang biasanya diakhiri oleh kadens setengah dan frase konsekwen yang diakhiri oleh kadens autentik (Indrawan, 2004: 22).

- Periode pararel, jika melodi pada frase kedua mirip dengan yang pertama, yang kemiripannya biasanya terdapat pada permulaan frase. Pada periode pararel setidaknya birama pertama dari konsekuen mirip dengan birama pertama anteseden (Stein, 1979: 39).

- Periode kontras, terjadi jika arah melodi pada frase konsekwen berbeda dengan arah melodi pada frase anteseden. Jadi walaupun ritme keduanya bisa mirip atau sama, namun jika arah melodi pada kedua frase berbeda maka disebut periode kontras (Stein, 1979: 42).

Setelah memahami bagian dari bentuk dan struktur serta unsur-unsur musik, yang merupakan dasar-dasar dalam studi analisis musik, dicoba untuk menganalisis struktur lagu. Pada bagian ini akan dicontohkan analisis struktur lagu Sepasang Mata Bola . Berikut notasi pada lagu sepasang mata bola : 


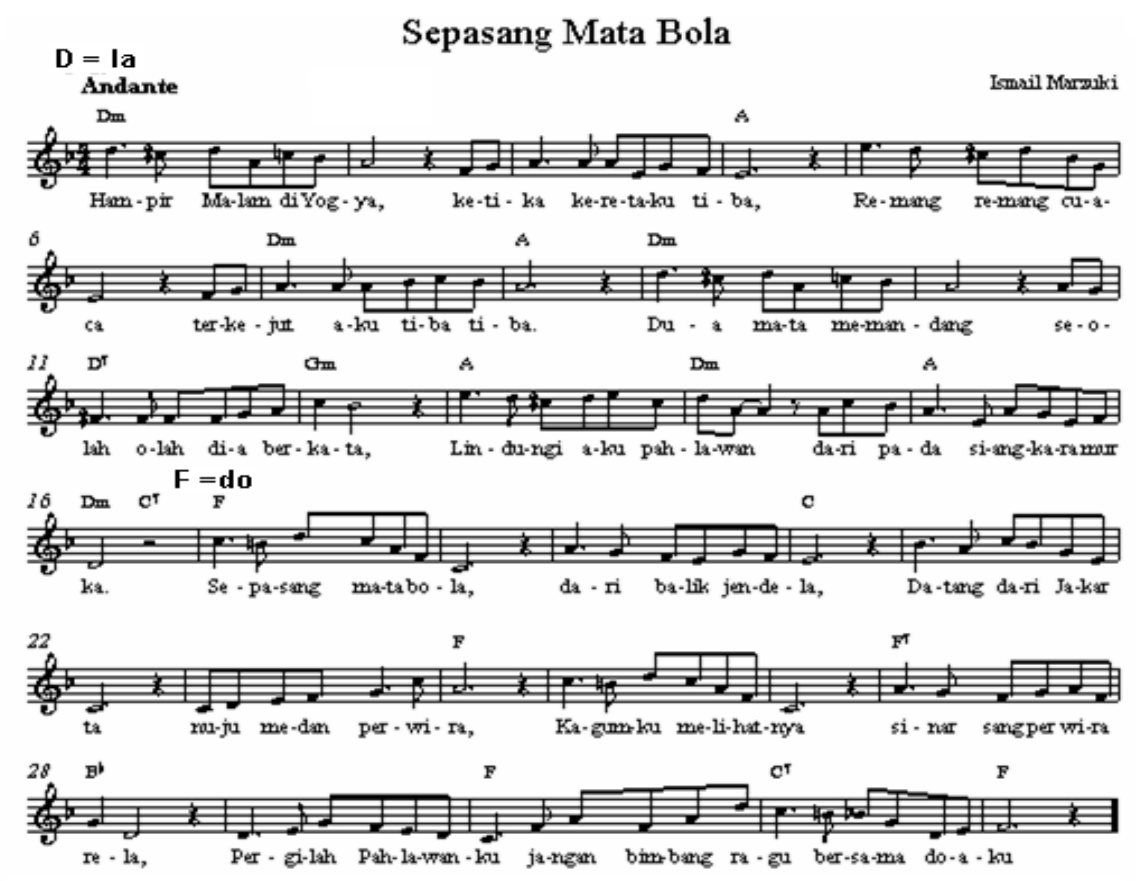

Notasi 1

Lagu Sepasang Mata Bola (Siagian, 1975:79)

Dari notasi di atas, dapat dilihat bahwa pada bagian awal lagu dari birama 1 samapai birama 16, lagu tersebut dimainkan pada tangga nada minor dengan nada dasar $D=$ la. Selanjutnya ada perubahan menjadi tangga nada mayor di bait kedua dengan nada dasar $F=$ do pada birama 17 sampai dengan birama 32. Tempo yang digunakan dalam lagu tersebut yaitu andante yang berarti agak lambat seperti kecepatan orang berjalan dengan metronom 69 - 75. Lagu tersebut sering dimainkan dengan irama keroncong dengan jenis langgam. Harmoni pada lagu tersebut dapat dilihat dari progresi akor yang mengikuti perjalanan melodi pokok.

Motif pada lagu tersebut mulai dari birama 1 ketukan 1 sampai birama 2 ketukan 3. Motif tersebut terus diulang dan dikembangkan sampai akhir lagu. Frase anteseden (tanya) mulai dari birama 1 ketukan 1 sampai birama 4 ketukan 3. Frase konsekwen (jawab) mulai dari birama 5 ketukan 1 sampai birama 8 ketukan 3 diakhiri dengan nada $A$ dari tangga nada $D$ minor, yaitu menggunkan kadens autentik tak sempurna. Struktur melodi pada periode A ini diulangi lagi pada periode A', tapi pada frase konsekwennya di 
akhiri dengan nada $D$ dari tangga nada $D$ minor, yaitu menggunakan kadens autentik sempurna. Pada periode $A$ dan A' dimainkan dalam tangga nada $D$ minor, dimana $A^{\prime}$ merupakan pengulangan dari periode $A$ tapi dengan modifikasi. Selanjutnya periode $B$ dan B' mengikuti struktur pada periode A dan A' tapi pada bagian ini dimainkan dalam tangga nada relatif mayornya yaitu $\mathrm{F}$ mayor.

Struktur pada lagu Sepasang Mata Bola mengunakan formula A, A', B, B', formula ini menunjukkan lagu tersebut termasuk lagu dua bagian (Miller, Tanpa Tahun: 168), periode A' dan B' merupakan sebuah pengulangan tema yang dimodifikasi. Untuk lebih jelasnya dapat dilihat pada notasi berikut :

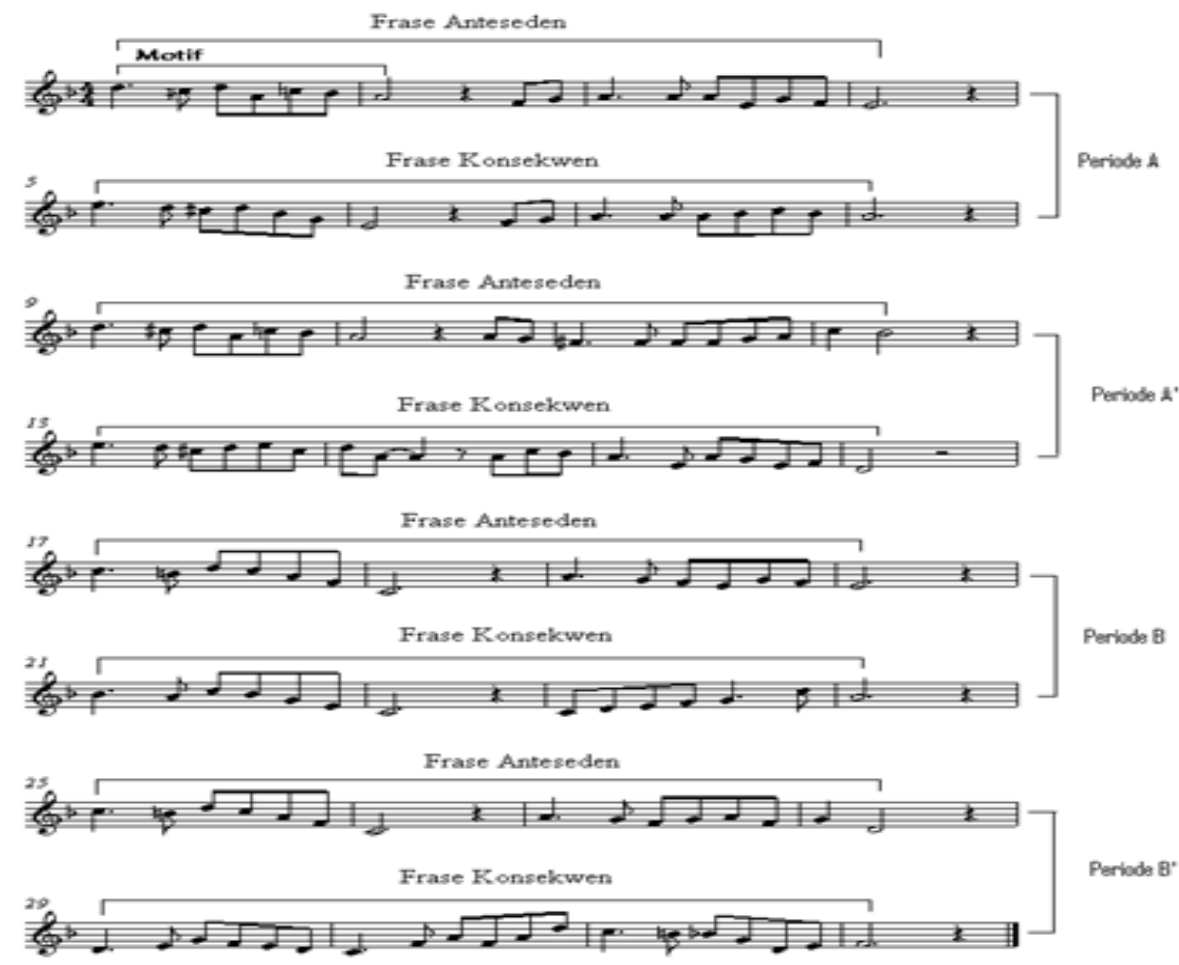

Notasi 2

Bentuk 2 bagian 


\section{Pemilihan Instrumen}

Menentukan instrumen dalam setiap aransemen merupakan hal yang bebas dilakukan. Namun penting bagi kita untuk mengetahui instrumen tersebut dalam berbagai sudut pandang. Dalam proses aransemen yang lebih dekat dengan sebuah kreativitas, register instrumen dan teknik-teknik permainan dalam instrumen tersebut penting untuk diketahui. Dengan memhamai hal tersebut pengolahan unsur musik seperti melodi, ritme, dan harmoni dari instrumen tersebut akan lebih kaya. Selain itu, penting juga bagi kita memahami karakter suara dan/atau bunyi instrumen, sehingga dalam menyatukan masingmasing instrumen akan ada pertimbangan tentang keseimbangan audio (balancing), dan kesan musik yang diinginkan.

Berikut ini akan dijelaskan sedikit tentang register dan teknik yang digunakan dalam instrumen gitar klasik dan instrumen gesek.

\section{Instrumen Gitar Klasik}

Gitar klasik menggunakan senar nilon dan menghasilkan suara yang lembut. Necknya lebih lebar dari gitar elektrik atau gitar yang lain dan cocok untuk bermain solo, biasanya dipetik dengan jari-jari. Nada-nada yang dihasilkan oleh gitar berada satu oktaf lebih rendah dari yang ditulis pada notasi, artinya penulisan notasi untuk gitar selalu ditulis satu okaf lebih tinggi dari pada nada yang dihasilkan. Gitar klasik ditala dengan urutan nada $E, A, d, g, b, e 1$.

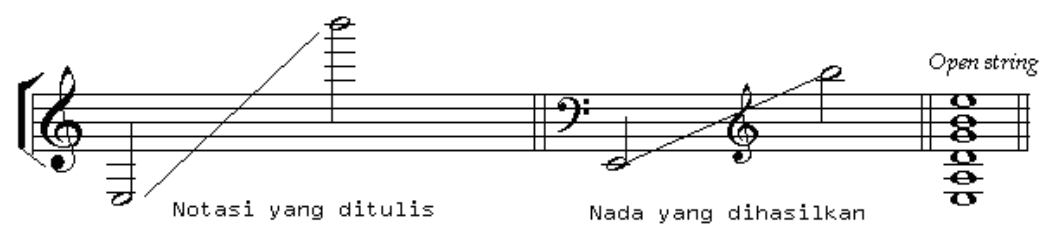

Notasi 3

Range pada gitar 
Gitar klasik memiliki suara yang khas, warna suara itu dapat dihasilkan dengan menggunakan teknik-teknik permainan gitar, ada beberapa teknik yang dapat digunakan untuk menimbulkan efek-efek suara tertentu, diantaranya :

\section{a. Armonicos}

Teknik ini dapat diterapkan pada fret $3,4,5,7,12,16$, dan 19. Cara memainkannya dengan menyentuh senar tanpa menekan fret yang disebutkan di atas, kemudian dipetik dengan tangan kanan. Dalam notasi biasanya letak fret dituliskan dengan angka. Berikut contoh penulisan teknik Armonicos pada notasi gitar, diambil dari Etude No.1 karya Heitor Villa- Lobos :

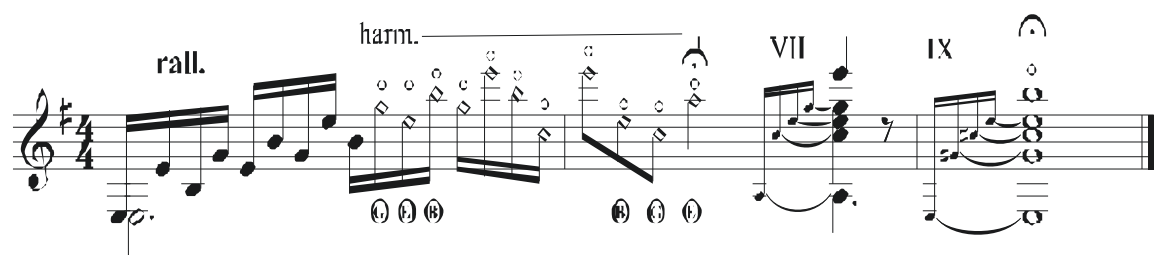

Notasi 4

Armonicos

b. Fagot

Cara memainkannya dengan meletakkan sisi tangan kanan tepat di atas senar tanpa ditekan diantara bridge dan lubang suara, kemudian dipetik dengan tangan kanan. Teknik ini akan menghasilkan suara fagot. Berikut contoh penulisan teknik Fagot pada notasi gitar, diambil dari Gran Jota Karya Francisco Tarrega :

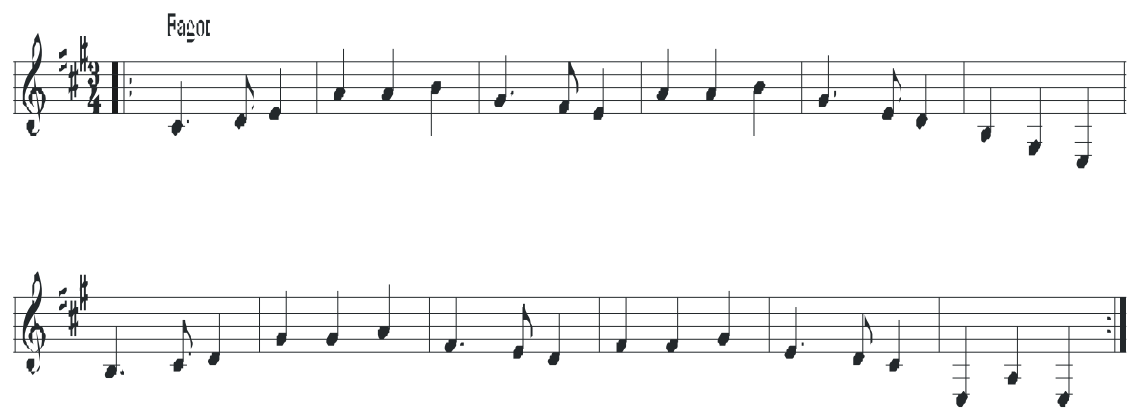

Notasi 5

Fagot 


\section{c. Tabalet}

Teknik ini menghasilkan efek suara seperti snare drum, cara memainkannya dengan memuntir senar lima dan enam di sekitar fret sembilan. Berikut contoh penulisan teknik tabalet pada notasi gitar, diambil dari Gran Jota Karya Francisco Tarrega :

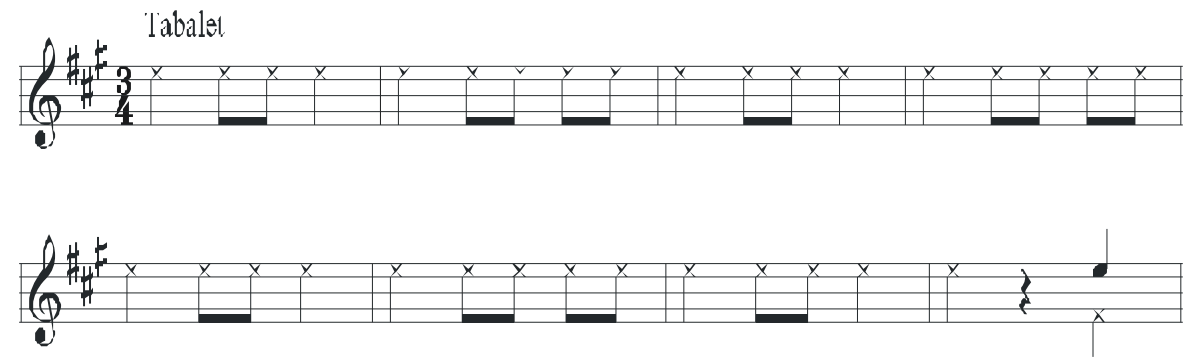

Notasi 6

Tabalet

d. Tambora

Cara memainkan teknik ini dengan memukul senar tepat di dekat bridge dengan menggunakan sisi ibu jari tangan kanan. Teknik ini menghasilkan suara seperti bas drum. Berikut contoh penulisan teknik tamborapada notasi gitar, diambil dari Aconquija Karya Agustin Barios Mangore :
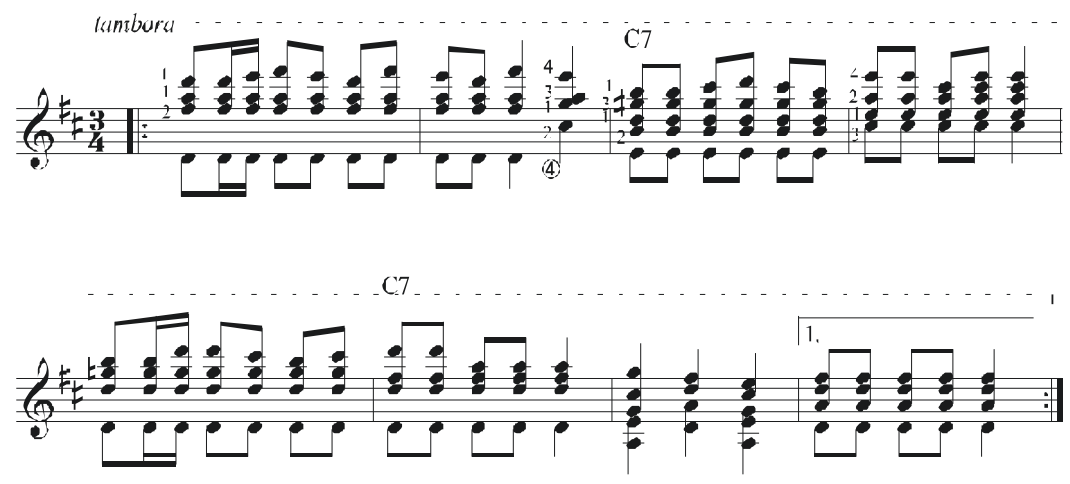

Notasi 7

Tambora 


\section{e. Pizzicato}

Teknik ini dihasilkan dengan menekan senar dekat bridge menggunakan tangan kanan, dipetik dengan ibu jari ataupun jari yang lain. Teknik ini menghasilkan efek suara yang lebih lembut pada instrumen gitar. Berikut contoh penulisan pizzicato pada notasi gitar, diambil dari Bercause karya Leo Brower

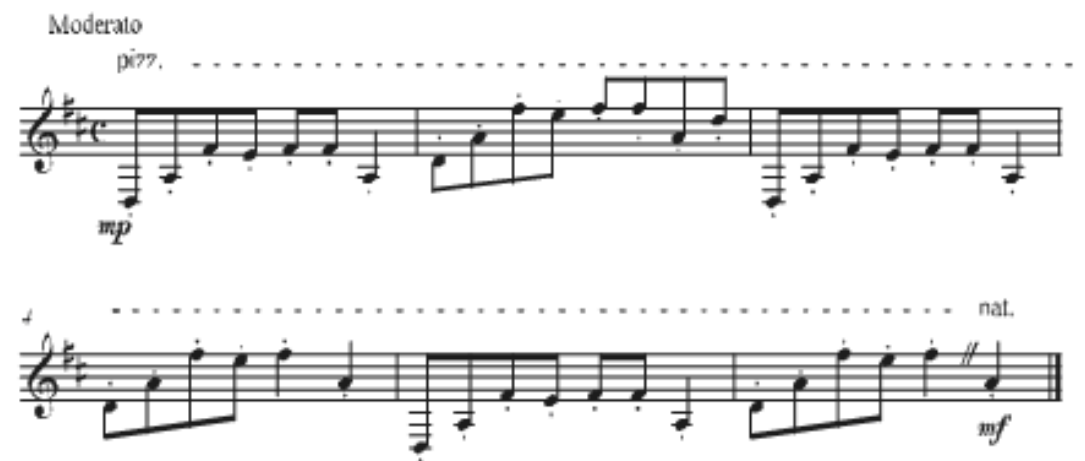

Notasi 8

Pizzicato

Selain sebagai instrumen solo, gitar dapat dijadikan sebagai instrumen pengiring. Saat ini gitar selalu dikaitkan dengan instrumen lain serta iringan lagu populer.

\section{Instrumen Gesek}

Instrumen gesek yang akan dijelaskan terdiri dari violin, viola dan violoncello. Berikut ini sedikit penjelasan tentang instrumen tersebut.

i. Violin

Violin mulai dipergunakan orang pada abad ke-16, seperti yang kita ketahui violin ditala dalam urutan nada $\mathrm{g}, \mathrm{d1}, \mathrm{a1}, \mathrm{e}$. Menurut riwayatnya senar violin terbuat dari usus kering, tetapi sejak abad ke-18 senar G dibuat dengan lilitan perak dan sejak tahun 1920 senar A dan E dibuat dari baja. Violin merupakan alat musik terkecil dalam format orkestra, nada-nadanya mempunyai register yang tinggi. 


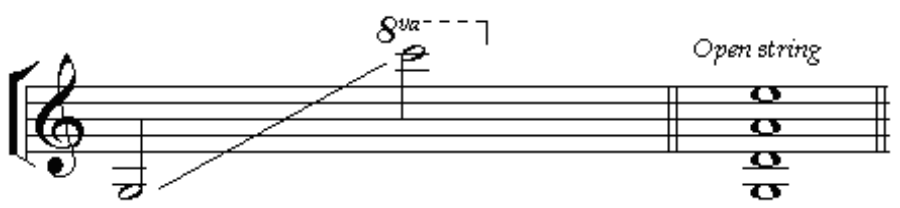

Notasi 9

Range pada violin

ii. Viola

Viola ditala satu kuin lebih rendah dari Violin dengan urutan nada c, g, d1, a1, notasinya dituliskan dalam paranada berkunci alto kecuali pada wilayah nada yang tinggi dapat berpindah ke kunci g.

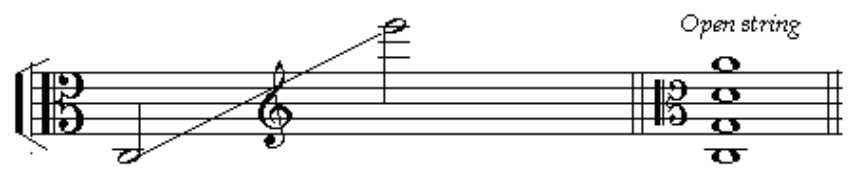

Notasi 10

\section{Range pada viola}

\section{iii. Violoncello}

Lebih dikenal sebagai celo, ditala dengan nada satu oktaf lebih rendah dibandingkan viola dengan urutan nada C, G, d, a. Instrumen ini dimainkan dalam keadaan duduk dengan mengepit alat ini di antara kedua lutut.

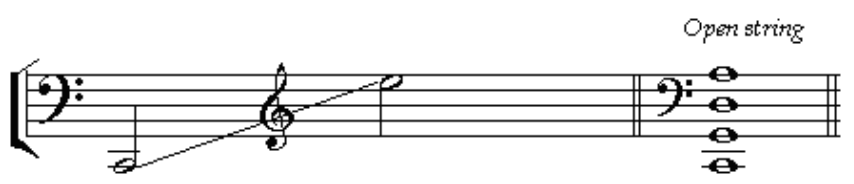

Notasi 11

\section{Range pada violoncello}

Pada instrumen gesek ada beberapa teknik permainan yang digunakan untuk menghasilkan efek suara yang berbeda. Dalam komposisi maupun aransemen musik, 
teknik-teknik tersebut sering digunakan oleh komposer untuk memperkaya komposisinya. Beberapa teknik permainan dalam instrumen gesek antara lain :

a. Legato

Teknik permainan dengan satu gesekan untuk memainkan dua nada atau lebih, legato dalam penulisan musik ditandai dengan sebuah garis lengkung di atas atau di bawah nada yang dimaksud, nada tersebut dimainkan secara bersambung. Berikut contoh penulisan legato pada notasi, diambil dari String quartet in Es major Op. 74 karya Beethoven Letter K birama 179-181 :

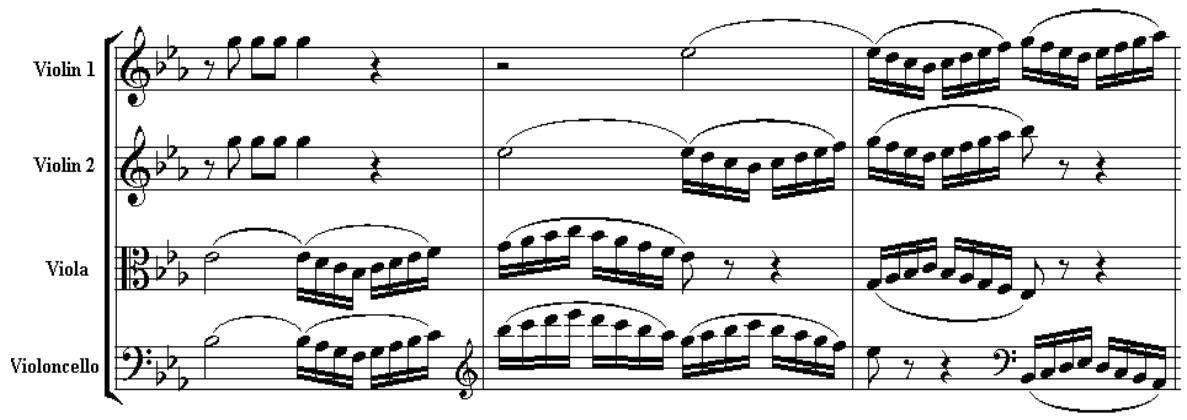

Notasi 12

$$
\text { Legato }
$$

\section{b. Staccato}

Teknik ini dilakukan dengan cara menggesek dawai dengan pendek dan tajam sehingga terdengar efek suara terputus-putus. Teknik ini biasanya dilakukan dengan satu gesekan untuk satu nada, pada saat melakukan gesekan dengan teknik staccato, bow atau penggesek tetap menempel pada dawai atau senar. Penulisan pada notasi ditandai dengan titik. Berikut contoh penulisan staccato pada notasi, diambil dari String Quartet in F major Op. 18 no. 1 karya Beethoven birama 274 - 279 : 


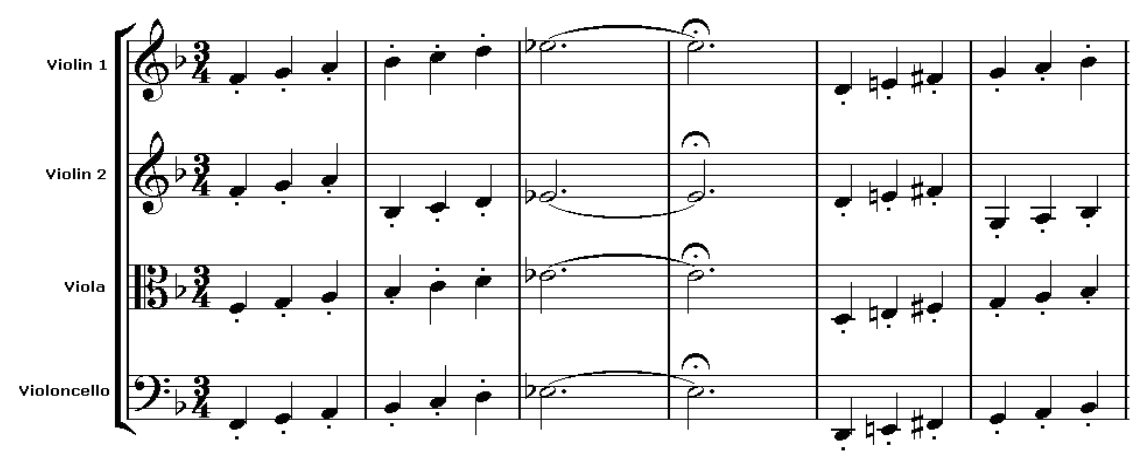

Notasi 13

Staccato

\section{Arpeggio}

Teknik ini menggesek untuk tiga atau empat nada pada dawai yang berlainan dalam gerakan nada ke atas maupun ke bawah. Teknik ini biasa dilakukan secara bersambung dalam gerakan ke atas maupun ke bawah. Berikut contoh teknik arpeggio pada notasi, diambil dari String quartet in Es major Op. 74 karya Beethoven Letter N birama 235 -237 untuk instrumen violin 1:

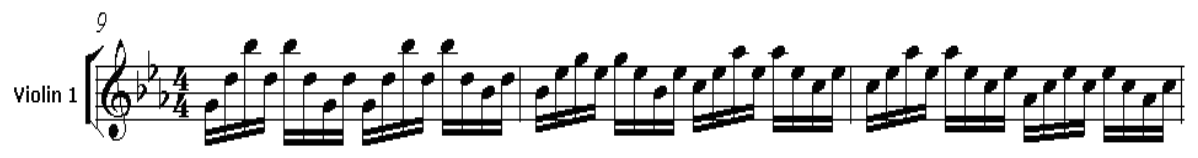

Notasi 14

Arpeggio

\section{d. Pizzicato}

Pizzcato merupakan teknik memetik dawai dengan menggunakan tangan kanan pada instrumen gesek. Secara umum digunakan dengan satu jari (telunjuk) atau jari dua (tengah) sedangkan dua jari memegang alat penggesek dengan hair bow menghadap pemain. Berikut contoh penulisan pizzicato pada notasi, diambil dari Peer Gynt Suites nomor 1 karya Edvard Grieg bagian IV birama 26-28 untuk instrumen violin satu dan violin dua : 


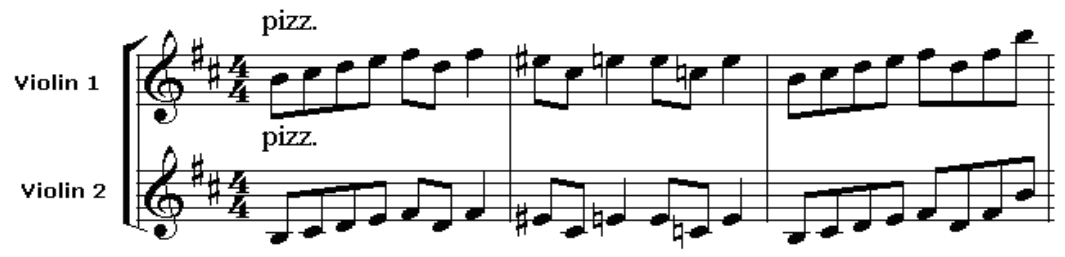

Notasi 15

Pizzicato pada instrumen gesek

\section{e. Sul ponticello}

Sebuah nada yang kering dan metalik yang dihasilkan dengan cara menggesek dekat bridge violin.

\section{f. Double stops}

Teknik menggesek dua senar secara serentak, biasanya untuk notasi yang menggunakan interval seperti, ters, kwart, quin, six, oktaf. Berikut contoh penulisan pizzicato pada notasi, diambil dari String quartet in Es major Op. 74 karya Beethoven bagian allegretto con variazioni variasi 5 birama 114-116 untuk instrumen violin 2 dan viola :

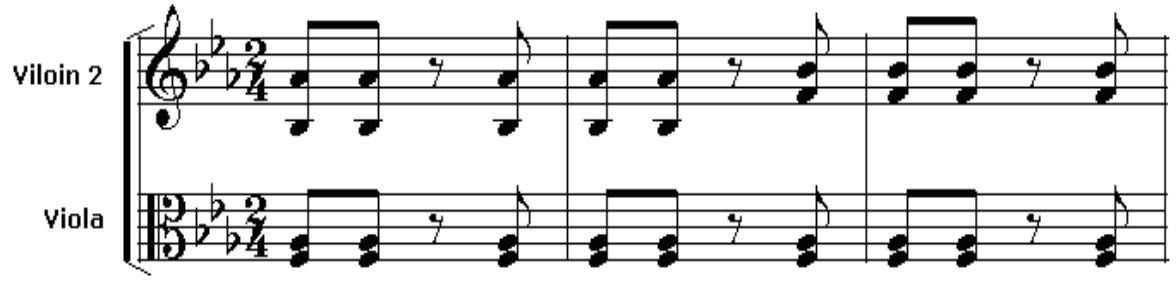

Notasi 16

Double stops 


\section{Pemilihan Bentuk Aransemen}

Pengertian aransemen yang digunakan sebagai landasan dalam mengaransemen sudah dijelaskan pada bagian pendahuluan, namun Bentuk aransemen haruslah kita tentukan sebelum mengaransemen. Dalam musik barat sudah ada bentuk yang konvensional untuk kita jadikan acuan dalam proses aransemen, salah satunya adalah bentuk tema dan variasi. Bentuk yang disebut tema dan variasi dipergunakan secara luas dalam periode klasik, baik sebagai sebuah lagu bebas atau sebuah bagian dari simfoni, sonata, atau kuartet gesek. Dalam sebuah tema dan variasi, satu ide musikal dasar (tema), diulang-ulang dan tiap kali dirubah sedemikian rupa. Bentuk ini dapat disimpulkan sebagai tema $(A)$, variasi $1\left(A^{\prime}\right)$, variasi $2\left(A^{\prime \prime}\right)$, variasi $3\left(A^{\prime \prime \prime}\right)$ dan sebagainya, setiap tanda pokok menandai sebuah variasi dari ide dasar (Kamien, 1998: 36).

Kerangka bentuk tema dan variasi ini meliputi dua langkah, yang pertama ada pernyataan tentang sebuah tema, biasanya dalam sebuah cara atau gaya yang sederhana dan langsung. Tema tersebut sering berupa sebuah bentuk nyanyian yang sederhana, untuk tema pokok itu sendiri komposer dapat membuat melodi yang original atau meminjam melodi orang lain. Yang kedua tema itu dinyatakan berulang-kali, setiap kali dengan beberapa pola modifikasi atau variasi yang diterapkan. Variasi-variasi dapat mencakup modifikasi yang luas sehingga ide yang asli menjadi tidak jelas (Miller, Tanpa Tahun: 182).

Setiap variasi biasanya mempunyai panjang yang sama. Perubahan melodi, ritme, iringan, dinamika, atau warna suara dapat digunakan untuk memberi ciri khas yang khusus dari sebuah variasi. Inti dari melodi dapat muncul dalam bass, atau dapat diulang dalam kunci minor selain kunci mayor. Inti melodi dapat terdengar bersamaan dengan sebuah melodi yang baru. Setiap variasi bersifat unik dan dapat berbeda dalam nuansa dari tema pokok (Kamien, 1998: 36-37).

Dari penjelasan di atas, dapat dikatakan bahwa dalam sebuah aransemen yang menggunakan bentuk tema dan variasi, melodi lagu dijadikan sebagai tema. Selanjutnya melodi dari lagu tersebut dikembangkan pada bagian variasi. Pengolahan struktur dan unsur musik dari lagu pada bagian variasi, akan dijelaskan pada bagian berikutnya. 
Namun yang terpenting adalah kita harus mencoba untuk memahami struktur dan unsurunsur musik pada lagu tersebut terlebih dahulu.

\section{Teknik Mengolah Struktur dan Unsur Musik Dari Lagu Pada Bagian Variasi}

Leon Stein memberikan beberapa prosedur pengolahan bentuk variasi yang khas pada abad ke-18 dan abad ke-19 dengan contoh karya J. Brahms Variation on a Theme Haydn for orchestra Op. 56a (Stein, 1979: 96-97), prosedur tersebut di antaranya :

1. Penggunaan harmoni yang sama dengan suatu melodi yang baru atau penggunaan melodi yang sama dengan harmoni yang baru.

2. Memberikan ornamentasi pada melodi atau menghiasi melodi.

3. Penggunaan bentuk melodi dari tema dan penggunaan suatu bentuk ritmik dari tema.

4. Perubahan gaya, perubahan tonika, perubahan sukat.

5. Mengolah dinamik atau membuat dinamik yang kontras disetiap frase maupun bagian.

6. Pengolahan register, penggunaan register yang rendah maupun yang tinggi, sepanjang variasi dapat membandingkan bagian dalam suatu variasi.

7. Mengolah tema dengan imitasi, canon, gerakan berlawanan, nada pengiring ganda, pelebaran tema atau perluasan motif dari tema, pengecilan tema atau penyempitan motif dari tema.

8. Perubahan warna, dapat diartikan sebagai mengolah warna suara yang ada pada setiap instrumen hal ini dapat dilakukan dengan memanfatkan teknik-teknik permainan dalam sebuah instrumen yang menghasilkan efek suara yang berbedabeda.

9. Materi dari variasi bukan dari tema yang sebenarnya.

10. Penggunaan pola struktural tema.

11. Penggunaan suatu jenis karakteristik seperti waltz, march, minuet.

12. Perluasan di dalam panjangnya variasi, dapat dilakukan dengan :

- Pengulangan suatu frase atau bagian

- Penyisipan suatu codetta

- Penambahan suatu bagian baru selama suatu variasi 
Leon Stein menjelaskan juga bahwa di dalam pengolahan bentuk variasi abad ke dua puluh berbeda dengan prosedur yang khas pada abad ke sembilan belas dan ke delapan belas (Stein, 1979: 98-99) seperti contoh :

1. Panjangnya dari tiap variasi, dalam tradisi klasik dan romantik bentuk dari tiap variasi jumlah birama sama dengan tema. Dalam abad 20 tipe tersebut menjadi perkecualian bukan sebagai aturan seperti contoh karya copland's variations for piano, pada variasi 12 terdiri dari 8 birama dan variasi 20 menjadi lebih panjang yaitu 53 birama.

2. Kebebasan dalam harmoni, variasi cenderung tidak mengikuti harmoni pada tema seperti yang digunakan pada abad - abad sebelumnya.

3. Lebih sedikit meperlihatkan materi dari tema yang sebenarnya, di dalam suatu jumlah yang lebih besar dari variasi keaslian dari tema dibuat cenderung menjadi lebih jauh atau tidak jelas.

4. Bebas dalam mengolah, pengolahan materi tematik ke arah suatu pengembangan bukannya variasi. Pada bagian lain motif ritmik dan melodi yang berasal dari tema dikembangkan tanpa mengacu pada tema.

5. Pengolahan warna suara dan irama memainkan peran yang lebih besar diabad ke-20 dibandingkan abad 18 dan 19.

Penjelasan Leon Stein di atas dapat dijadikan sebagai satu landasan dalam mengolah unsur-unsur musik pada saat proses aransemen. Namun masih banyak hal-hal yang perlu di ketahui lagi terkait dengan teknik mengolah unsur-unsur musik tersebut. Hal yang mendasar adalah bagaimana kita dapat mengembangkan motif, frase, dan periode, serta unsur musik yang berkenaan dengan ritme, melodi, harmoni, dinamika, tempo, ekspresi sesuai dengan hasil analisis lagu yang sudah kita lakukan sebelumnya. Misalnya, kita mengembangkan satu melodi lagu dengan interpelasi (menyisipkan nada), augmentasi (memperbesar nilai nada), sekwen (membuat pola ritme yang sama tapi di tingkat yang berbeda, diminusi (memperkecil nilai nada).

\section{Penulisan Notasi}

Setelah kita menjalani proses aransemen, maka selanjutnya penting untuk didokumentasikan dalam bentuk notasi agar aransemen tersebut dapat dimainkan. Ada banyak cara yang dapat digunakan dalam penulisan notasi, seperti notasi balok, notasi 
angka, dan diagram-diagram tertentu sesuai dengan kesepakatan. Dalam hal ini notasi maupun diagram yang digunakan merupakan simbol bunyi, yang akan dimainkan oleh instrumen musik. Tinggal bagaimana kita menjelaskan notasi tersebut kepada pemain musiknya agar dapat dimainkan sesuai dengan keinginan yang mengaransemen. Oleh karena itu, dalam menuliskan notasi perlu pemahaman teori yang berkenaan dengan musik tersebut. Berikut ini dua contoh penulisan notasi yang dapat digunakan :

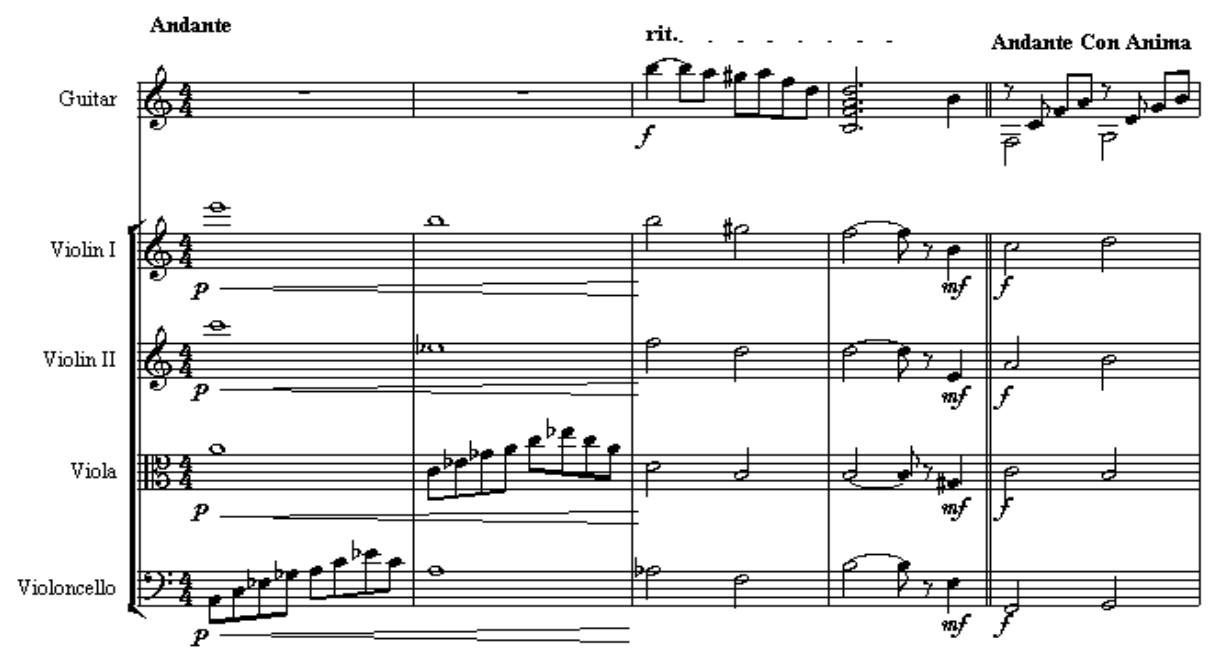

Notasi 3

Penulisan Dengan Notasi Balok

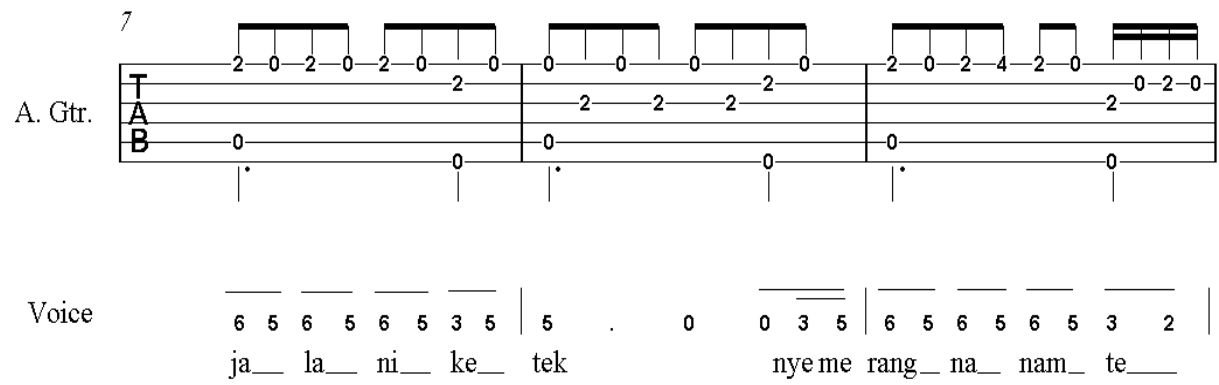

Notasi 4

Penulisan Dengan Notasi Angka dan Tabulatu 


\section{D.SIMPULAN}

Kegiatan mengaransemen lagu dimulai dengan memahami latar belakang komponis dan makna dari teks lagu tersebut. Hal ini dapat menjadi stimulan dalam mencari ide-ide musikal, yang nantinya digunakan dalam aransemen musiknya. Setelah itu, dilakukan analisis bentuk dan struktur lagu, yang meliputi penggalian motif, frase dan kalimat lagunya. Selain itu perlu dipahami unsur-unsur musik yang digunakan dalam lagu tersebut, meliputi melodi ataupun tangga nada yang digunakan, tempo, irama, harmoni, ekspresi, dan dinamika. Analisis bentuk dan struktur lagu ini dapat dijadikan pijakan dalam mengaransemen musik. Pengembangan struktur lagu dan unsur-unsur musik tersebut merupakan bagian dari kegiatan mengaransemen musik.

Kegiatan terakhir adalah menetukan instrumen dan bentuk musik pada aransemen lagunya. Dalam menentukan instrumen setiap arranger memiliki kebebasa secara musikal, namun diperlukan wawasan tentang instrumen tersebut, seperti teknik, warna suara, dan register instrumennya. Hal ini akan menjadi acuan dalam mengolah unsur-unsur musik pada aransemen lagunya. Setelah itu, menentukan bentuk musik yang akan digunakan dalam aransemen lagunya. Dalam bentuk tema dan variasi melodi lagu dijadikan tema, sedangkan variasi lagu dibuat dengan mengembangkan tema yang sudah di analisis sebelumnya.

Aransemen musik merupakan sebuah kreativitas, yaitu bagian dari proses mengembangkan dan/atau menjadikan suatu karya menjadi lebih artistik dan memiliki nilai estetis. Hal ini merupakan suatu kegiatan yang menarik untuk dilakukan bagi kalangan musisi khsusnya. Oleh karena itu, perlu hal-hal yang mendukung proses kreatif tersebut, seperti yang telah dijelaskan di atas. Artikel ini merupakan sebuah penawaran dalam melakukan proses tersebut. Hal yang paling mendasar dari sebuah proses adalah menanamkan sikap dengan sungguh-sungguh, mencoba untuk belajar dan belajar untuk mencoba. Dengan mengikuti proses yang dijelaskan pada artikel ini diharapkan dapat membantu dalam kegiatan mengaransemen lagu. 


\section{DAFTAR PUSTAKA}

Ammer, Christine, Harper's Dictionary of Music, Barnes and Noble Books a Division of Harper an Row, New York, Hager Stown, San Fransisco, London, 1972.

Banoe, Pono, 2003, Kamus Musik, Kanisius, Yogyakarta. 1984, Pengantar Pengetahuan Alat Musik, CV. Baru, Jakarata

Boyd, Malcolm, 1980, Arrangement dalam Stanley Sadie, The New Grove Music and Musician, in twenty volumes, Macmillan Publishers Limited, London.

Esha, Teguh... (et al.), 2005, Ismail Marzuki : Musik, Tanah Air dan Cinta,Pustaka LP3ES Indoneia, Jakarta.

Harjana, Suka, 2004, Esai dan Kritik Musik, Galang Pers, Yogyakarta.

Indrawan, Andre, 2004, "IImu Analisis Musik 1", Jurusan Musik FSP ISI Yogyakarta.

Jones, George Thaddeus, 1974, Music Theory, Barnes and Noble Book, New York.

Kamien, Roger, 1998, Pendekatan Sejarah Musik (II) Melalui Apresisasi Musik, Terjemahan Triyono Bramantyo dari Music, an Appreciation, McGraw-Hill Book Co., Jurusan Musik FSP ISI Yogyakarta, Yogyakarta.

Kawakami, Genichi, 1975, Arranging Popular Music : A Practical Guide, Yamaha Music Foundation, Tokyo, Japan.

Kennan, Kent, dan Grantham, Donald, 1990, The Technique Of Orchestration, The University of Texas at Austin, Prentice Hall, Englewood, New Jersey.

Kodijat, Latifah, 1986, Istilah-Istilah Musik, Penerbit Djambatan, Milik DEPDIKBUD RI, Jakarta.

Miller, M. Hugh, tanpa tahun, Pengantar Apresiasi Musik, diterjemahkan oleh Triyono Bramantyo PS. dari Introduction to Music : A Guide to Good Listening, Institut Seni Indonesia Yogyakarta, Yogyakarta.

Prier, Karl Edmund SJ., 1993, Sejarah Musik Jild 2, Pusat Musik Liturgi, Yogyakarta.

Randel, Don Michael, 1986, 'arangement' The New Harvard Dictionary of Music,London : The Belknap Press of Harvard Univerity Press.

Sadie, Stanley, 1980, The New Grove Music and Musician, in twenty volumes, Macmillan Publishers Limited, London. 
Scholes, Percy A., Arangement or Transcription, The Oxford Companion to Music Tenth Edition, $\quad$ London : Oxford University Press, Tanpa Tahun.

Siagian, M. Pardosi, 1975, Indonesia Yang Ku Cinta, Penyebar Musik Indonesia, Yogyakarta.

Stein, Leon, 1979, Structure and Style : The Study and Analysis of Musical Form, Summy - $\quad$ Birchard Music, Expand Edition New Jersey, USA.

Sumarni, C. SP, 1991, "Gaya Bahasa Komponis Ismail Marzuki Dalam Lirik Lagu-lagu Ciptaannya", Balai Penelitian ISI Yogyakarta, Yogyakarta.

Susilo, Y. Edhi, 1999, "Lagu-Lagu Perjuangan Pada Masa Revolusi Fisik", Lembaga Penelitian Institut Seni Indonesia Yogyakarta. 